During germination of Tropaeolum soeds starch grains appear in the cells of the cotyledons. It is uncertain whether this arises from the slowly disappearing amyloid, or from the oil in the cells. A remarkable fact is that in unripe seeds the cellwalls do not show the amyloid reaction, whereas the cells contain much starch. Only in the very last phase of ripening does amyloid appear while the starch disappears wholly. Therefore it is likely that amyloid in Tropaeolum is stable only during the resting period of the seed.

Details of these investigations will be published elsewhere.

Technical University,

\section{P. Kootman}

Delft.

Oct. 13.

${ }^{1}$ Mitchell, E. M., Amer. J. Bot., 17, 117 (1930).

${ }^{2}$ Winterstein, E., Z. physiol. Chem., 17, 353 (1893).

${ }^{3}$ Krishna, S., and Ghose, T. P., Indian Forest Leaflet, Forest Research Institute, Dehra Dun, No. 23 (1942) and No. 47 (1943).

+ Savur, G. R., and Sreenivasan, A., Current Sci., 15, 43 (1946).

s Frank, A. B., Jahrb. Wiss. Bot., 5, 161 (1866).

"Linsbauer, K., "Handbuch der Pfianzenanatomie", Abt. II, 2, 10 (1926).

\section{Differential Insecticide Damage in Maize Varieties}

A Mixture of three parts of ethylene dichloride and one part of carbon disulphide (by volume) applied at the rate of $0 \cdot 6$ c.c./litre of storage space by pouring the liquid on to the surface has been effective for some years in preventing insect damage to maize grain (var. Tsolo) stored in closed bins for subsequent sowing. In 1956 the variety Mexican Elite was grown instead of Tsolo, and the grain after storage was found to have a very low germination capacity. A series of experiments was carried out to test the hypothesis that the insecticide was affecting the grain adversely, and that some varieties of maize were more susceptible than others to this treatment.

Grain of each of four varieties of maize was divided into two portions, one being kept as control and the other given the normal insecticidal treatment. Ten days later, seventy-eight grains from each of the treated and untreated samples of each variety were planted in garden soil under conditions suitable for germination. After seven days the number of plants that had germinated was determined by counting the number of shoots that had emerged. These results are summarized in Table 1.

Many of the emergent seedlings from the treated grain were distorted, and in order to obtain a measure of this distortion and the resultant stunting of the shoots, all seedlings were harvested at the first node and weighed on the eighth day after sowing. The results are summarized in Table 2.

It can be seen from the tables that in every instance treatment of the grain resulted in an increase in the number of plants that failed to emerge, and that response to the treatment differed from variety

Table 1. Percentage Germination of Treated and Untreathd Grain, SEVEN DAYS aFrer SOWING

\begin{tabular}{|c|c|c|}
\hline \multicolumn{1}{|c|}{ Variety } & Untreated & Treated \\
\hline Lagos White & 97 & 90 \\
Abakallki Red & 99 & 77 \\
Mexican x Sie & 91 & 81 \\
Trinidad & 97 & 86 \\
\hline
\end{tabular}

Table 2. Mean Fresh Whight of Shoots (IN GM.) on Eighth DaY

\begin{tabular}{|c|c|c|c|c|c|c|}
\hline \multirow{2}{*}{ Variety } & \multicolumn{2}{|c|}{ Untreated } & \multicolumn{2}{|c|}{ Treated } & \multirow{2}{*}{$\begin{array}{l}\text { S.E. of } \\
\text { diff. }\end{array}$} & \multirow{2}{*}{$\begin{array}{c}p \\
\text { (per cent) }\end{array}$} \\
\hline & $m$ & $\delta^{2}$ & $m$ & $\delta^{2}$ & & \\
\hline $\begin{array}{l}\text { Lagos White } \\
\text { Abakaliki Red } \\
\text { Mexican } \times \text { Sie } \\
\text { Trinidad }\end{array}$ & $\begin{array}{l}2 \cdot 15 \\
2 \cdot 05 \\
1 \cdot 78 \\
1 \cdot 82\end{array}$ & $\begin{array}{l}0.48 \\
0.42 \\
0 \cdot 31 \\
0.26\end{array}$ & $\begin{array}{l}1.76 \\
1.85 \\
1.04 \\
0.27\end{array}$ & $\begin{array}{l}1 \cdot 06 \\
0 \cdot 50 \\
0 \cdot 31 \\
0 \cdot 05\end{array}$ & $\begin{array}{l}0 \cdot 15 \\
0 \cdot 12 \\
0 \cdot 09 \\
0.06\end{array}$ & $\begin{array}{c}1 \\
5-10 \\
<0 \cdot 1 \\
<0 \cdot 1\end{array}$ \\
\hline
\end{tabular}

to variety both in this respect and also in the degree of stunting suffered by the seedlings that did emerge. Further, the suppression of germination and the stunting of growth are not necessarily parallel. On one hand, in Abakaliki Red the germination was strongly suppressed, but the majority of seedlings from the treated grain showed normal growth. On the other hand, in Trinidad, the treatment did not markedly affect germination but caused severe stunting.

It would seem desirable that the effect of the above insecticidal mixture on the viability of maize grain should be determined before this method of protection is employed for seed corn.

F. E. S. Alexander

University College,

H. T. Clinford

Ibadan,

Nigeria.

\section{Lungworm from Rats captured in Britain}

Doring the period December 1954-April 1956, the lungs of a total of 191 wild rats from Cambridge, Cardiff, Liverpool, London, Nottingham, St. Albans and Wolverhampton were examined for lungworms. They included 24 Rattus rattus. L. and 167 Rattus norvegicus Erkl. It was only possible to examine fresh lungs of nine Rattus rattus from London. The remaining lungs were collected by ataff of the Infestation Control Division of the Ministry of Agriculture, Fisheries and Food. They were preserved in 10 per cent formalin and examined later. None of these rat lungs was infested with Angiostrongylus cantonensis (Chen., 1935), and in no case did the lung tissue appear to be abnormal pathologically.

Table 1 shows the number of rats examined from each location. The Rattus rattus were collected from British ports.

\begin{tabular}{|l|c|c|c|}
\hline \multicolumn{1}{|c|}{ Table 1 } \\
\hline Locality & Rattus norvegicus & Rattus rattus & Total \\
\hline Cambridge & 51 & - & 51 \\
Cardiff & 35 & 5 & 40 \\
Liverpool & 2 & 10 & 12 \\
London & 58 & - & 9 \\
Nottingham & 4 & - & 58 \\
St. Albans & 17 & - & 17 \\
Wolverhampton & 167 & 24 & 191 \\
\hline Total & & & \\
\hline
\end{tabular}

In examining several hundreds of wild rats from England over a number of years, Mr. F. R. N. Pester, London School of Hygiene and Tropical Medicine, has not observed any lungworm infestations (personal communication).

In the present survey, although the results from the examination of such a small number of rat's 